The Economic Journal of Nepal, Vol. 42, No. 3 \& 4, July-December 2019 (Issue No. 152) C Cedecon-TU

\title{
Role of Inflow of Resources on Economic Growth of Nepal
}

\author{
Tilak Singh Mahara ${ }^{15}$ \\ Naw Raj Bhatt ${ }^{16}$
}

\begin{abstract}
This study attempts to examine the role of the inflow of resources on the economic growth of Nepal incorporating annual time-series data sets of 45 years from 1975 to 2019. The autoregressive distributed lag approach to cointegration is used to identify the long-run as well as the short-run relationship between the variables. The empirical finding indicates that there is a positive relationship between the inflow of resources and economic growth. Quantitatively, gross national saving, domestic loans, foreign loans, and export earnings have a positive impact on the economic growth in both the long-run as well as short-run for the Nepalese economy. Policies encouraging private sector participation, enlarging efficiency, and effectiveness of public sector projects, and expanding export base must be implemented.
\end{abstract}

Key words: Resources, Deficit financing, Economic growth, ARDL

\section{Introduction}

Economic growth is a steady process by which the productive capacity of an economy increases over time to bring about rising levels of national output and income (Todaro \& Smith, 2017). One of the chief aims of the macroeconomic policies of the nation is to achieve sustained economic growth. It is a decisive way of improving living standards as well as achieving the economic development of an economy. The inflow of resources in the form of savings, borrowing, investment, remittance, export earnings, etc. has been believed to play an important role in stimulating the economic development of a country. For developing countries like Nepal, the inflow of foreign resources in the form of a foreign loans, foreign grants, foreign direct investment, etc. along with domestic saving work as major inputs for the economic advancement of the country.

In the least developed countries like Nepal, a deficit budget has been formulating and taking as a means for achieving steady growth of output by generating additional financial resources for the development undertakings. The deficit budget can be financed either by internal or external sources. Domestic sources include internal borrowing, savings, the printing of more

${ }^{15}$ Lecturer at the Everest Innovative College (EIC), Solteemode, Kathmandu, Nepal, Emailmaharatilak1@gmail.com

${ }^{16}$ Graduate Scholar of Economics at the Central Department of Economics, Tribhuvan University, Kirtipur, Kathmandu, Nepal, Email- bhattanr92@gmail.com 
currencies and putting them into circulation, etc. Among these domestic sources, savings and internal borrowing are the major sources of financing investment expenditures. Likewise, the external sources consist of external loans, foreign direct investment, grants, and gifts. The government of the least developed countries like Nepal has been accepting foreign grants and also been borrowing from a foreign government (bilateral source) and international organizations (multilateral source) to finance its deficit budget.

Nepal has been one of the foreign resources receiving countries in different forms since the establishment of democracy. Nepal received foreign aid for the first time in 1951 (Bhattarai, 2019). Since then the country has been receiving bilateral and multilateral foreign assistance and taking a foreign loan to finance the deficit budget to achieve steady economic growth. Despite the constant inflow of external resources, Nepal remains one of the poorest countries in the world. The empirical examination of the effects of different forms of inflow of resources on the economic growth of Nepal is crucial to ascertain the role of such inflows. Therefore, the study aims to investigate the effect of domestic saving, domestic borrowing, foreign debt, and export earnings on the economic growth of Nepal. The findings of the study are expected to identify the relative effectiveness of different sources of financing investment expenditure and formulation of policies accordingly.

\section{Review of Literature}

\section{Theoretical Review}

The Harrod-Domar model suggests that the rate of economic growth is based on the rate of savings in the economy. The rate of savings is positively associated with the rate of economic growth. Higher savings enable greater investment in capital stock, and that leads to increase in the growth rate of output. Harrod-Domar model as a closed economy model does not include the role of foreign resources in the economic growth of the host / receiving country (Harrod, 1939; Domar, 1946).

The Solow growth model emphasized that the level of output in an economy over time is the result of a change in savings rate along with population growth rate and rate of technological progress. Thus, the saving rate in the Solow model enters as an implicit determinant of economic growth (Solow, 1956).

The dual gap model or two gap model designed by Harrod (1939) and Domar (1946) supports the need for foreign resources inflow in the form of foreign aid or foreign borrowing of capital by developing nations for achieving rapid economic growth. Thus, on the one hand, the model argues that most of the developing countries face a lack of domestic savings to finance the required investment to achieve desired economic growth, and on the other hand, shortage of foreign exchange needed to import necessary capital goods and raw materials for industrialization. Two gap theories, thus, advocate that there is a crucial role of inflow of foreign resources to mitigate domestic savings and foreign exchange gap faced by developing countries.

Classical economists argued in favour of a balanced budget. However, they argued that borrowing will be meaningful if there is an increase in public expenditure without an increase in the revenues and this borrowing must be used in the financing of productive sectors (Weber, 1947). 
Neo-classical economists believe that increasing the inflow of resources through public debt is disadvantageous because an expansionary fiscal policy increases current consumption, which leads to the decline of the saving rate. Consequently, the interest rate rises, and which leads to declining private investment, and ultimately there is a crowd out of investment and capital, and a reduction in economic growth in the long run (Dahal, 2014).

Keynesian economists are in the favour of the role of the government in the form of a deficit budget and public borrowing. The government should adopt a surplus budget and cut the inflow of resources in any form in the inflationary state. The government needs to formulate a deficit budget and raise the inflow of resources in the form of public borrowing to uplift aggregate demand and economic growth especially in the case of depression and recession.

\section{Empirical Review}

Sothan (2017) examined the effect of foreign aid, investment, and trade openness on the economic growth of Cambodia using the study period from 1980 to 2014. The study has used the autoregressive distributive lag bounds testing approach. The analysis found that trade openness has a positive effect on growth; investment has a positive effect on growth only in the long run and foreign aid has a positive impact on growth only in the short run whereas foreign aid hurts both growth and investment in the long run. The author suggested that the long-term dependence on foreign aid would not positively contribute to the growth of Cambodia and policymakers should move from foreign aid dominance to the promotion of private domestic and foreign investment for sustainable development.

Sabra and Eltalla (2016) explored the role of foreign aid, trade openness, domestic investment and domestic savings on economic growth in the eight Middle East and North African (MENA) countries. The study used a simultaneous equation model and dynamic panel data system analysis covering the data span from 1977 to 2013. Authors found that there is a negative relationship between economic growth and foreign aid and foreign aid seems to crowd out domestic savings. They also found a significantly positive effect of trade openness and domestic investment on the economic growth of said countries.

Chamlagai (2015) examined the effectiveness of remittance foreign aid, FDI, and labour force on the economic growth for Nepal covering the data sets of 45 years from 1970 to 2014. By using the ARDL approach to co-integration, the study found that remittance and labour forces are important driving factors for output growth in the case of Nepal whereas investment, FDI, and Aid do not have any significant impact on output growth.

Basnet (2013) investigated the effects of foreign aid on domestic savings and economic growth in five South Asian countries. The study used a simultaneous equation system and covered the period 1960 to 2008. The results indicate that aid has a positive and significant effect on the growth rates of the five nations Bangladesh, India, Nepal, Pakistan, and Sri Lanka. The study also found that foreign aid seems to crowd out domestic savings rather than complementing.

Tiwari (2011) studied the effects of foreign aid, foreign direct investment, capital stock, labour force, and economic freedom on economic growth in 28 Asian countries using panel data for the period 1998 to 2007. The study used static and dynamic panel data techniques and found that there is a positive relationship between fiscal freedom, financial freedom, domestic capital 
stock, and economic growth whereas, there is a negative impact of freedom from corruption, the inflow of foreign direct investment, and foreign aid on economic growth.

Ekanayake and Chatarana (2010) analyzed the effect of foreign aid on the economic growth of different 85 developing countries from Asia, Africa, and Latin America, and the Caribbean for the period 1980 to 2007 . They employed a panel data series for foreign aid and tested the hypothesis that foreign aid can promote growth in developing countries. The study found that foreign aid has mixed effects on economic growth in developing countries.

Baharumshah and Thanoon (2006) studied the effect of FDI, foreign debt, and domestic savings on the economic growth of East Asian countries including China. The authors used panel data covering the period from 1982 to 2001 and used dynamic generalized least square methodology. They found that domestic saving has a positive effect on long-term economic growth; FDI has a positive effect on both the long-run and short-run growth, and foreign debt has a positive effect on only short-run growth. They also confirmed that FDI has a significantly strong effect on the growth process of East Asian countries.

Dahal (2003) examined the impact of domestic savings and foreign loans on the economic growth of Nepal covering the data of 26 years from 1975 to 2000. The study employed the Engle-Granger co-integration and error correction model (ECM) and found that there is a positive impact of both domestic savings and foreign loans on economic growth. Similarly, the author found that there is bidirectional causality between domestic saving and economic growth and there is no causality between foreign loans and economic growth. The coefficient of domestic savings in the study was found greater than that of foreign loan and thus the study suggested that policymakers should incorporate policies towards mobilization of domestic savings to finance investment expenditure.

Ahmad (1986) analyzed the effect of foreign capital inflow on domestic saving in Bangladesh by using the single equation method and two stages least square method. The study covered the data of 20 years from 1961 to 1980. The analysis has found a positive but statistically insignificant effect of foreign capital inflow on domestic saving in the case of two stages least square method and significantly negative in the case of the single equation method.

Papanek (1973) examined the association between foreign aid, foreign private investment, saving, and growth in the less developed countries. The cross-country regression analysis is applied to 34 countries for the 1950 s and 51 countries for the 1960 s using the ordinary least square method. Considering foreign aid, foreign investment, other inflows, and domestic savings as distinct independent variables, the study found a positive effect of these factors in the growth. The elasticity coefficient of foreign aid was found greater than that of any other variables.

\section{Research Methodology}

\section{Data Sources and Variables}

The study uses annual time-series data of 45 years from 1975 to 2019. The required data are collected from the Nepal Rastra Bank (NRB), the central bank of Nepal as well as the Ministry of Finance (MoF). The nominal form of the variables is converted into the real term by dividing the value of the GDP deflator at constant prices of the base year 2001. Here, real gross domestic product (RDGP) is the inflation-adjusted measure of the monetary value of economic output 
produced at a given time within the economy. Gross national saving is the resulting amount after deducting final consumption expenditure from Gross national disposable income. A domestic loan is a credit taken by the government from internal sources like public or private organizations, the central bank, commercial banks, and other financial institutions within a country. Similarly, the loan borrowed by the government from foreign sources like foreign governments and international institutions to finance its resource gap is foreign loan. The earnings of a country that are made via the exports of goods and services are export earnings. These factors are considered as the major sources to fulfil the resource gap in Nepal.

Table-1: Description of Variables

\begin{tabular}{|l|l|l|c|l|}
\hline S.N. & Notation & \multicolumn{1}{|c|}{ Variable } & Unit & \multicolumn{1}{c|}{ Source } \\
\hline 1 & RGDP & $\begin{array}{l}\text { Real Gross Domestic } \\
\text { Product (2001=100) }\end{array}$ & In Rs million & $\begin{array}{l}\text { Current Macroeconomic and } \\
\text { Financial Situation-2018/19, NRB }\end{array}$ \\
\hline 2 & GNS & Gross National Saving & In Rs million & Macroeconomics Dashboard, MoF \\
\hline 3 & DL & Domestic Loans & In Rs million & Macroeconomics Dashboard, MoF \\
\hline 4 & FL & Foreign Loans & In Rs million & Macroeconomics Dashboard, MoF \\
\hline 5 & X & Exports Earning & In Rs million & $\begin{array}{l}\text { Current Macroeconomic and } \\
\text { Financial Situation-2018/19, NRB }\end{array}$ \\
\hline
\end{tabular}

\section{Model Specification}

The model in the study displays a functional relationship between dependent and independent variables. Real gross domestic product (RGDP) is considered as a dependent variable, and gross national saving (GNS), domestic loans (DL), foreign loans (FL), and export earnings $(\mathrm{X})$ are employed as explanatory variables. Based on the theoretical literature and following Dahal (2003), the functional form can be stated as

$$
\mathrm{RGDP}=\mathrm{f}(\mathrm{GNS}, \mathrm{DL}, \mathrm{FL}, \mathrm{X})
$$

The explicit form of equation (1) shows the linear relationship between the dependent and explanatory variables as shown in equation (2),

$$
\operatorname{LnRGDP}=\beta_{0}+\beta_{1} \operatorname{LnGNS}+\beta_{2} \operatorname{LnDL}+\beta_{3} \operatorname{LnFL}+\beta_{4} \operatorname{LnX}+\mathrm{U}_{\mathrm{t}} \ldots \ldots \ldots
$$

Here, Ln refers to the natural logarithm, $\beta_{0}$ is intercept; $\beta_{1}, \beta_{2}, \beta_{3}$, and $\beta_{4}$ are respective coefficients to be estimated and $U$ is the error term and t stands for the time. The respective coefficients are expected to have a positive sign indicating an increase in the values of LnGNS, LnDL, LnFL, and LnX lead to an increase in the volume of LnRGDP. 


\section{ARDL Approach to Cointegration}

The ARDL model developed by Pesaran and Shin (1999) and Pesaran, Shin and Smith (2001) is one of the widely used and most suitable approaches to check the co-integration relationship between the underlying variables irrespective of whether the variables are integrated of order zero (I0), one (I1) or mutually integrated. Using the ARDL approach to cointegration has numerous advantages in comparison to other co-integration methods such as Engle-Granger (1987), Johansen (1988), and Johansen and Julius (1990) procedures (Shah and Bhusal, (2017). This procedure is also deemed a statistically more significant approach to determine the co-integrating relation in small samples. The ARDL version of equation (2) is expressed as below.

$$
\begin{gathered}
\Delta \text { LnRGDP }_{\mathrm{t}}=\alpha_{0}+\sum_{\mathrm{j}=1}^{\mathrm{p}} \mathrm{b}_{\mathrm{j}} \Delta \operatorname{LnRGDP}_{\mathrm{t}-\mathrm{j}}+\sum_{\mathrm{j}=0}^{\mathrm{q}} \mathrm{c}_{\mathrm{j}} \Delta \operatorname{LnGNS}_{\mathrm{t}-\mathrm{j}}+\sum_{\mathrm{j}=0}^{\mathrm{r}} \mathrm{d}_{\mathrm{j}} \Delta \operatorname{LnDL}_{\mathrm{t}-\mathrm{j}}+ \\
\sum_{\mathrm{j}=0}^{\mathrm{s}} \mathrm{e}_{\mathrm{j}} \Delta \mathrm{LnFL}_{\mathrm{t}-\mathrm{j}}+\sum_{\mathrm{j}=0}^{\mathrm{t}} \mathrm{f}_{\mathrm{j}} \Delta \operatorname{LnX}_{\mathrm{t}-\mathrm{j}}+\gamma_{1} \operatorname{LnRGDP}_{\mathrm{t}-1}+\gamma_{2} \operatorname{LnGNS}_{\mathrm{t}-1}+ \\
\gamma_{3} \operatorname{LnDL}_{\mathrm{t}-1}+\gamma_{4} \operatorname{LnFL}_{\mathrm{t}-1}+\gamma_{5} \operatorname{LnX}+\mathrm{U}_{\mathrm{t}} \ldots \ldots \ldots \ldots \ldots \ldots \ldots \ldots \ldots \ldots \ldots \ldots \ldots \ldots \ldots \ldots \ldots \ldots \ldots \ldots \ldots
\end{gathered}
$$

Where ' $\Delta$ ' stands for the first difference operator. bj, cj, dj, ej and fj symbolize the short-run parameters whereas, $\gamma_{1}, \gamma_{2}, \gamma_{3}, \gamma_{4}$, and $\gamma_{5}$ represent the long-run parameters. Similarly, Ut represents the error term in the model.

To test whether the long-run equilibrium relationship exists between selected variables, the bounds test for co-integration is carried out as proposed by Pesaran and Shin (1999). The hypotheses to test the long-run relationship are.

Null Hypothesis $\left(H_{0}\right): \gamma_{1}=\gamma_{2}=\gamma_{3}=\gamma_{4}=\gamma_{5}=0$; No co-integration exists.

Alternative Hypothesis $\left(\mathrm{H}_{1}\right): \gamma_{1} \neq \gamma_{2} \neq \gamma_{3} \neq \gamma_{4} \neq \gamma_{5} \neq 0$; Co-integration exists.

If the result obtained from the bound test shows the co-integration then there exists a longterm relationship among the variables. For this, F-statistics is compared with the critical values provided by Pesaran, Shin and Smith (2001). If the computed F-statistics is higher than the appropriate upper bound of the critical values, the null hypothesis of no co-integration is rejected, if it is below the appropriate lower bound, the null hypothesis cannot be rejected, and if it lies within the lower and upper bounds, the results is inconclusive.

\section{Results and Discussion}

\section{Unit Root Test Results}

A stationary time series is the one, statistical properties of which is that the mean and variance are constant over time and the covariance between two time periods is time-invariant. If the time-series data are non-stationary then there is the problem of spurious regression (Gujarati et al., 2012). Thus, examining the stationary of data is essential before doing any sort of empirical analysis.

There are various methods of checking unit roots in the series like the Dickey-Fuller (DF), Augmented Dickey-Fuller (ADF), Phillips-Perron (PP), and Kwiatkowski-Phillips-SchmidtShin (KPSS) test. This study uses the ADF and PP test to diagnose the stationary of data and the results are shown in Table-2. 
Table-2: Results of ADF and PP Test

\begin{tabular}{|l|c|c|c|}
\hline \multicolumn{1}{|c|}{ Variables } & ADF-Statistics & PP-Statistics & Order of Integration \\
\hline LnRGDP & $-7.4697^{*}$ & $-7.6085^{*}$ & $\mathrm{I}(1)$ \\
\hline LnGNS & $-7.2754^{*}$ & $-7.5444^{*}$ & $\mathrm{I}(1)$ \\
\hline LnDL & $-5.4497^{*}$ & $-9.0709^{*}$ & $\mathrm{I}(1)$ \\
\hline LnFL & $-5.9976^{*}$ & $-6.1066^{*}$ & $\mathrm{I}(1)$ \\
\hline LnX & $-5.3444^{*}$ & $-5.287^{*}$ & $\mathrm{I}(1)$ \\
\hline
\end{tabular}

Note: * coefficients are significant at 1 percent level of significance

Source: Authors' computation

As shown in Table-2, the underlying variables are non-stationary at level but stationary after first differencing, that is, all the variables are integrated of order one. Here, all the variables are not ordered more than one hence the ARDL model can precede.

\section{Correlation Matrix}

A correlation matrix is a table showing the direction and degree of association between sets of variables. It is a powerful tool to summarize a large data set and to identify and envisage patterns in the given data. If the inter-correlation between explanatory variables is high, say more than 0.80 , then there may be the problem of multi-collinearity. Table- 3 shows the results of the inter-correlation coefficient of all the variables used in the study.

Table-3: Correlation Matrix of the Variables

\begin{tabular}{|l|c|c|c|c|c|}
\hline Variables & LnRGDP & LnGNS & LnDL & LnFL & LnX \\
\cline { 1 - 3 } LnRGDP & 1.0000 & & & & \\
\cline { 1 - 3 } LnGNS & 0.9766 & 1.0000 & & & \\
\cline { 1 - 3 } LnDL & 0.8429 & 0.8146 & 1.0000 & & \\
\cline { 1 - 4 } LnFL & 0.5134 & 0.3777 & 0.5376 & 1.0000 & \\
\cline { 1 - 5 } LnX & 0.7909 & 0.7243 & 0.5168 & 0.4132 & 1.0000 \\
\hline
\end{tabular}

Source: Authors' computation

The results show that there is no possibility of high multi-collinearity issues between explanatory variables. Thus, these variables can be used in the standard model of the study.

\section{Lag Length Selection}

The assortment of an appropriate order of lag for the ARDL model is essential to identify the co-integrating relationship among the variables. The optimal lags selected by different criteria based on the VAR lag selection approach are presented in Table-4. 
Mahara \& Bhatt : Role of Inflow of Resources on Economic.... | 73

Table-4: VAR lag Order Selection Criteria

\begin{tabular}{|c|c|c|c|c|c|c|}
\hline Lag & LogL & LR & FPE & AIC & SBIC & HQ \\
\hline 0 & -83.6561 & NA & 0.000052 & 4.32469 & 4.53366 & 4.40078 \\
\hline $\mathbf{1}$ & 160.689 & 488.69 & $1.2 \mathrm{e}-09 *$ & $-6.37509^{*}$ & $-\mathbf{- 5 . 1 2 1 2 6 *}$ & $-5.91851^{*}$ \\
\hline 2 & 177.363 & 33.347 & $1.9 \mathrm{e}-09$ & -5.96892 & -3.67023 & -5.13187 \\
\hline 3 & 199.637 & 44.547 & $2.5 \mathrm{e}-09$ & -5.83594 & -2.49238 & -4.6184 \\
\hline 4 & 226.183 & $53.093^{*}$ & $3.2 \mathrm{e}-09$ & -5.91137 & -1.52295 & -4.31335 \\
\hline
\end{tabular}

Note: * indicates lag order selected by the criterion; LR: sequential modified LR test statistic (each test at $5 \%$ level); FPE: Final prediction error; AIC: Akaike information criterion; SBIC: Schwarz Bayesian information criterion; HQ:

Hannan-Quinn information criterion.

Source: Authors' computation

\section{Cointegration Results}

Table-5 presents the bound test result regarding the co-integration relationship between real GDP and explanatory variables.

Table-5: Bound Test Results

\begin{tabular}{|c|c|c|c|c|c|}
\hline Variables & F-statistics & \multicolumn{3}{|c|}{ Critical Values } & \multirow{2}{*}{ Lag Option } \\
\cline { 3 - 5 } & & $\begin{array}{c}\text { Level of } \\
\text { signification }\end{array}$ & $\mathrm{I}(0)$ & $\mathrm{I}(1)$ & \\
\hline $\begin{array}{c}\text { F(LnRGDP I } \\
\text { LnGNS, LnDL, } \\
\text { LnFL, LnX) }\end{array}$ & \multirow{3}{*}{3.991} & $10 \%$ & 2.45 & 3.52 & \multirow{2}{*}{$(1,0,0,0,1)$} \\
\cline { 3 - 5 } & & $5 \%$ & 2.86 & 4.01 & \\
\cline { 3 - 5 } & $1 \%$ & 3.74 & 5.06 & \\
\hline
\end{tabular}

Source: Authors' computation

The bound test result displayed in the table-5 shows that the calculated F-statistics 3.991 is greater than the upper bound critical value 3.52 at a 10 percent level of significance. This shows the rejection of the null hypothesis of no cointegration. So, it can be said that there exists a longterm relationship between the selected variables.

\section{ARDL Regression Results and Interpretation}

Given the existence of co-integration between real GDP and different sources of inflow of resources, the long-run and short-run coefficients for equation (3) were estimated using the ARDL model. Thus, the long-run and short-run relationships among variables with the help of the ARDL model based on the SBIC criterion are presented in the following section. 
Table-6: Long-run Coefficients from ARDL $(1,0,0,0,1)$ Model

\begin{tabular}{|l|c|c|c|}
\hline \multicolumn{4}{|c|}{ Dependent Variable: LnRGDP } \\
\hline \multicolumn{1}{|c|}{ Variables } & Coefficients & Std. Error & t-Stat [Prob.] \\
\hline LnGNS & $0.501 *^{*}$ & 0.0681 & $7.36[0.000]$ \\
\hline LnDL & 0.0439 & 0.0549 & $0.80[0.430]$ \\
\hline LnFL & $0.1905^{*}$ & 0.0571 & $3.34[0.002]$ \\
\hline LnX & 0.0635 & 0.0667 & $0.95[0.347]$ \\
\hline C & $4.7595^{*}$ & 0.46587 & $10.21[0.000]$ \\
\hline $\begin{array}{l}\text { R-squared: } 0.99925 ; \text { Adjusted R-squared: 0.99913; Durbin-Watson stat: } 2.3776 ; \\
\text { F-Statistic: } 8275.161 \text { [0.0000] }\end{array}$ \\
\hline
\end{tabular}

Source: Authors' computation.

Note: * indicates that the coefficients are significant at a 1 percent level of significance.

Table- 6 presents the long-run coefficients from the selected ARDL model. As expected, the coefficients of all the explanatory variables are positive but varying in terms of statistical significance. LnGNS and LnFL are statistically significant at a 1 percent level of significance but LnDL and LnX are insignificant. The coefficients of LnGNS and LnFL are 0.5014 and 0.1905 state that with one percent increase in respective variables will lead to an increase in real GDP on an average by 0.5014 and 0.1905 percent respectively. Looking at the size of coefficients, the effect of gross national saving on real GDP is higher than that of foreign loan. This finding is parallel with Dahal (2003).

Table-7: Short-run Coefficients from ARDL $(1,0,0,0,1)$ Model

\begin{tabular}{|l|c|c|c|}
\hline \multicolumn{4}{|c|}{ Dependent Variable: $\Delta$ LnRGDP } \\
\hline \multicolumn{1}{|c|}{ Variables } & Coefficients & Std. Error & t-Stat [Prob.] \\
\hline$\Delta \mathrm{LnGNS}$ & $0.0523^{*}$ & 0.0170 & $7.0645[0.0041]$ \\
\hline$\Delta \mathrm{LnDL}$ & 0.0045 & 0.0062 & $0.7279[0.4712]$ \\
\hline$\Delta \mathrm{LnFL}$ & $0.0198^{*}$ & 0.0057 & $3.4343[0.0015]$ \\
\hline$\Delta \mathrm{LnX}$ & $0.0703^{*}$ & 0.0156 & $4.4998[0.0001]$ \\
\hline $\mathrm{ECM}(-1)$ & $-0.1044^{* *}$ & 0.0396 & $-2.630[0.0123]$ \\
\hline \multicolumn{2}{|c|}{ R-squared: $0.5344 ; \quad$ Adjusted R-squared: $0.4589 ; \quad$ F-Statistic: $8.495[0.0000]$} \\
\hline ECM=LnRGDP - 0.5014*LnGNS - 0.0439*LnDL - 0.1905*LnFL - 0.0635*LnX- 4.7595*C \\
\hline
\end{tabular}

Note: *and ${ }^{* *}$ indicate the significant at 1 and 5 percent level of significance respectively. Source: Authors' computation

The table-7 signifies the short-run dynamics of the model. Except for the coefficient of the domestic loan $(\Delta \mathrm{LnDL})$, all the other coefficients presented in the table show a positive and statistically significant short-run effect on real GDP ( $\triangle \mathrm{LnRGDP}$ ). Unlike the long run, the effect of export earnings $(\Delta \mathrm{LnX})$ in the short run is statistically significant and higher than the effect of other variables. Comparatively, the effect of all the variables in the short-run is lesser than that of the long-run. 
The value of the error correction term (ECM (-1)) is -0.1044 with a 5 percent level of significance. The negative and statistically significant value of the error correction term shows that the model is convergent towards equilibrium. Furthermore, it shows the speed of adjustment towards the previous year's disequilibrium to the current years. The result expresses that the adjustment speed is 10.44 percent per annum. It means that the deviation in the shortrun equilibrium converges to the equilibrium at the speed of 10.44 percent per annum.

Likewise, the value of R-squared is 0.5344 , which means 53.44 percent of the total variation in the real GDP is explained by gross national saving, domestic loan, foreign loan as well as export earnings in the short-run, and the remaining 46.56 percent is due to error. As compared to the long-run model, the value of R-squared is slightly low, but this does not significantly affect results since the variables are in difference form. Further, the probability of F-statistic having 0.000 confirms that the short-run model is significant.

Table-8: Results of the Diagnostic Test for Selected Model

\begin{tabular}{|l|l|l|}
\hline \multicolumn{1}{|c|}{ Test Statistics } & \multicolumn{1}{c|}{ LM Version } & \multicolumn{1}{c|}{ F Version } \\
\hline A: Serial Correlation & CHSQ (1): $2.0976[0.148]$ & $\mathrm{F}(1,36): 1.8022[0.188]$ \\
\hline B: Functional Form & CHSQ (1): 2.8466 [0.092] & $\mathrm{F}(1,36): 2.4901[0.123]$ \\
\hline C: Normality & CHSQ (2): $2.5757[0.276]$ & Not applicable \\
\hline D: Heteroscedasticity & CHSQ (1): 2.4548 [0.117] & $\mathrm{F}(1,42): 2.4817[0.123]$ \\
\hline
\end{tabular}

Note: a) Lagrange multiplier test of residual serial correlation; b)Ramsey's RESET test using the square of the fitted values; c)Based on a test of skewness and kurtosis of residuals; d) Based on the regression of squared residuals on squared fitted values.

Source: Authors' computation

The diagnostic test signifies that the model passes all the tests. The null hypothesis of the normality of residuals, no first-order serial correlation, no heteroscedasticity, and no misspecification of functional form are accepted as both LM and $F$ version exhibits the $p$-values more than the 5 percent level. This means the model is free from serial correlation, heteroscedasticity, functional form misspecification, and the issue of normality.

\section{Stability Test}

The stability test is used to measure the consistency of the parameters of the estimated model. The cumulative sum of recursive residuals (CUSUM) and cumulative sum of squares of recursive residuals (CUSUMSQ) statistics have been applied to measure the structural stability in the model. The null hypothesis for the stability test is that the coefficient is consistent. Under the null hypothesis, the value of the sequence outside an expected range suggests a structural change in the model over time. Systematic change in the parameter is measured by CUSUM whereas a sudden change in the parameter is measured by CUSUMSQ. 
76 | The Economic Journal of Nepal (Issue No. 152)

Figure-1: Plot of CUSUM Test

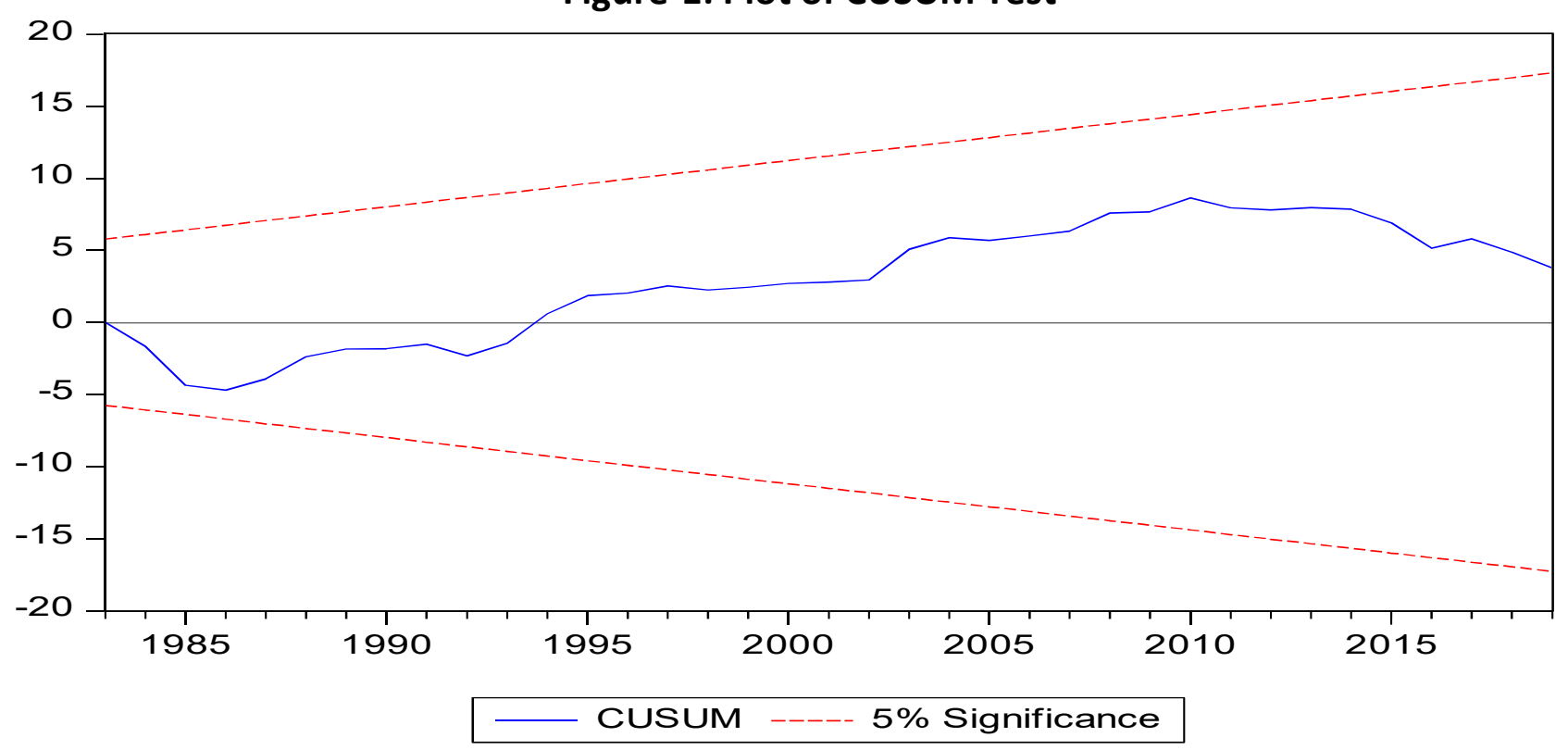

Source: Authors' computation

Figure-2: Plot of CUSUMSQ Test

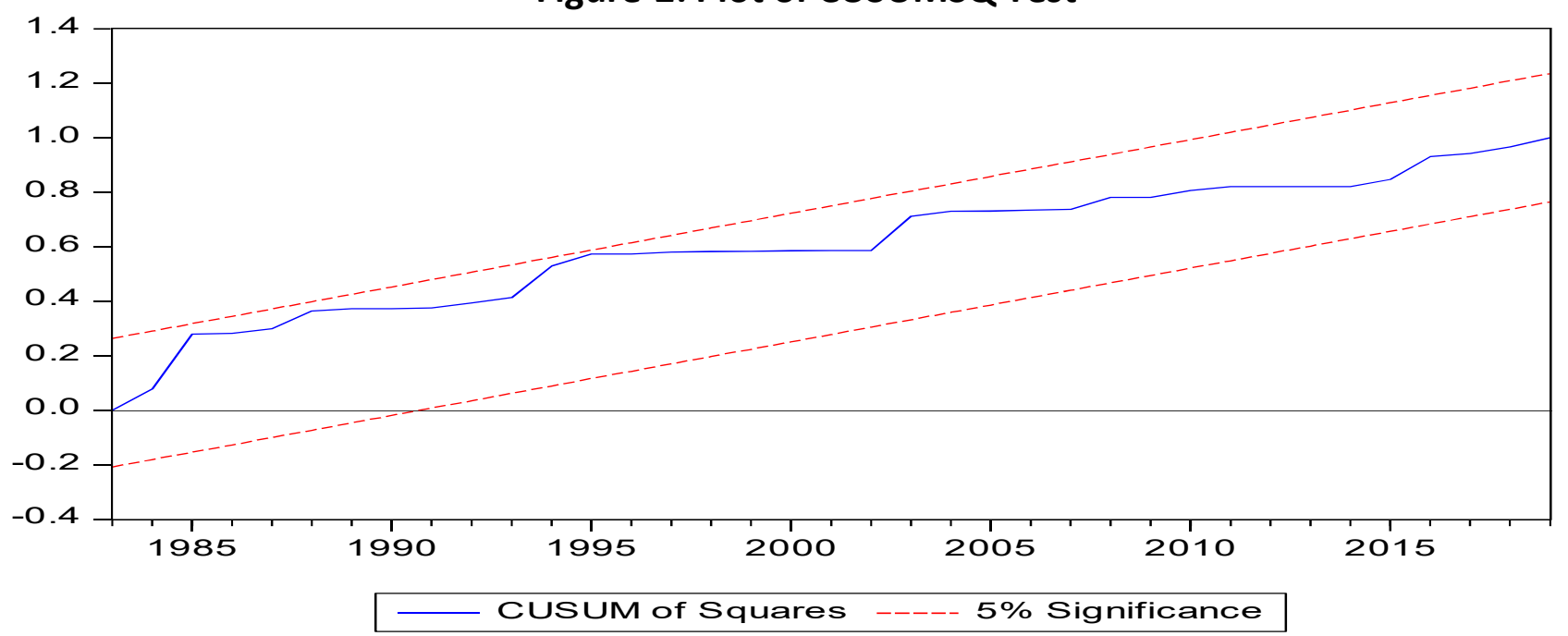

Source: Authors' computation

The plots of CUSUM and CUSUMSQ lines lie within the 5 percent critical bounds as shown in figure 1 and figure 2 . This proves that the model is stable and robust.

\section{Conclusion}

Filling the resource gap in developing countries like Nepal is one of the fundamental macroeconomic issues. The study attempts to examine the contribution of different sources of deficit financing to the economic growth of Nepal. The results of the study show that there is a positive effect of gross national saving, internal borrowing, export earnings, and foreign loans on economic growth in the case of the Nepalese economy. Only gross national savings and foreign loans significantly affect economic growth both in the long run and short run. However, 
export earnings significantly contribute to economic growth only in the short run. The negative and statistically significant coefficient of error correction mechanism $(\operatorname{ECM}(-1))$ reconfirms the long-term association between underlying variables. It also shows that there is disequilibrium in the short-run, and it converges towards equilibrium at the speed of 10.44 percent per annum.

The result also verified that the contribution of gross national saving to the growth is higher than that of foreign loans both in the long run as well as the short run. The only short-run contribution of export earnings may be due to a narrow concentration of Nepalese exports, export of low value-added products, lack of trade diversification in terms of countries and commodities, and geographical constraints, etc.

The empirical results of the study suggest to policymakers that Nepal needs to give chief importance to circulate domestic savings. To do so the private sector needs to be inspired so that the nation would get needed finance from domestic sources rather than going for external borrowing. Similarly, the fiscal efficiency and effectiveness of public sector projects in all the layers of the government must be enhanced to finance their investment expenditure. Through this, the implementation of public-private partnerships approach, as well as mobilization of private sector savings in the infrastructural development, can be achieved. Policies directed to encourage trade diversification, enhancing the competitiveness of domestic industries through the concepts like special economic zone (SEZ), and fuller utilization of facilities and privileges obtained as a landlocked and least developed country from different international organizations are if effectively implemented will ultimately increase the value of Nepalese products and expand the export base.

However, FDI, remittance, and foreign grant are not covered in the model. Assessment of causes of low productivity of foreign borrowing and statistically insignificant contribution of domestic borrowing to growth could be the future scope of the study.

\section{References}

Ahamad, S. (1986). Domestic savings and foreign capital inflow: The case of Bangladesh. The Bangladesh Development Studies, 14(1), 75-91.

Baharumshah, A. Z., \& Thanoon, M. A.-M. (2006). Foreign capital flows and economic growth in East Asian countries. China Economic Review, 70-83.

Basnet, H. C. (2013). Foreign aid, domestic savings, and economic growth in South Asia. International Business and Economics Research Journal, 12(11), 1389-1394.

Bhattarai, K. D. (2019, July 19). Six decades of American aid. Retrieved from https://theannapurnaexpress.com/news/six-decades-of-american-aid-1746

Chamlagai, D. (2015). The impact of remittance, foreign aid and FDI on growth: Evidence from the Nepal economy. Eastern Mediterranean University, Institute of Graduate Studies and Research, Famagusta: North Cyprus.

Dahal, M. P. (2003). Impact of domestic and foreign resources in the economic growth of Nepal. Economic Journal of Development Issues, 4(1), 42-57.

Dahal, M. P. (2014). Public debt stock, education-centric human capital and economic growth in Nepal. Economic Journal of Development Issues, 17(1), 76-104.

Domar, E. (1946). Capital expansion, rate of growth, and employment. Econometrica, 14(2), 137-147. 
Ekanayake, E. M., \& Chatrna, D. (2010). The effect of foreign aid on economic growth in developing countries. Journal of International Business and Cultural Studies, 1-13.

Gujarati, D. N., Porter, D. C., \& Gunasanker, S. (2012). Basic econometrics. New Delhi: McGraw Hill Education Private Limited.

Harrod, R. F. (1939). An essay in dynamic theory. The Economic Journal, 49(193), 14-33.

MoF (Ministry of Finance) (2019). Macroeconomics Dashboard. Retrieved from Government of Nepal Ministry of Finance: https://data.mof.gov.np/

NRB (Nepal Rastra Bank) (2019). Current Macroeconomic and Financial Situation of Nepal2018/19. Kathmandu: Nepal Rastra Bank.

Papanek, R. F. (1973). Aid, foreign private investment, savings and growth in less developed countries. Journal of Political Economy, 81(1), 120-130.

Pesaran, M. H., \& Shin, Y. (1999). An autoregressive distributed lag modelling approach to cointegration analysis. In I. S. Strom, Ecnometrics and Economic Theory in the 20th Century, The Ragner Frisch Centennial Symposium (pp. 371-413). Cambridge: Cambridge University Press.

Pesaran, M. H., Shin, Y., \& Smith, R. J. (2001). Bounds testing approaches to the analysis of level relationships. Journal of Applied Econometrics(16), 289-326.

Sabra, M. M., \& Eltalla, A. H. (2016). Foreign aid, domestic savings and economic growth in selected MENA countries. Business and Economic Research, 6(1), 352-362.

Shah, R. K., \& Bhusal, T. P. (2017). Nexux between public expenditure and economic growth in Nepal. The Economic Journal of Nepal, 148, 28-43.

Solow, R. (1956). A contribution to the theory of economic growth. The Quantity Journal of Economics, 7(1), 65-94.

Sothan, S. (2017). Foreign aid and economic growth: Evidence from Combodia. The Journal of International Trade and Economic Development, 1-16.

Tiwari, A. K. (2011). Foreign aid, FDI, economic freedom and economic growth in Asian countries. Global Economy Journal, 11(3).

Todaro, M. P., \& Smith, S. C. (2017). Economic development (12 ed.). Pearson India Education Services Pvt. Ltd.

Weber, M. (1947). The theory of economic and social organization. New York: Henderson and Talcott Parsons. 